V. Fatkhutdinov ${ }^{1}$, orcid.org/0000-0003-1231-5379, L. Yarmol ${ }^{2}$, orcid.org/0000-0001-8465-8579, T. Musiiets ${ }^{3}$, orcid.org/0000-0003-4291-5543, O. Lagovska ${ }^{4}$, orcid.org/0000-0001-9517-0499, I. Kryukova ${ }^{\mathbf{5}}$, orcid.org/0000-0002-0577-6364
1 - Interregional Academy of Personnel Management, Kyiv, Ukraine, e-mail: mfkoorg@gmail.com

2 - Lviv Polytechnic National University, Lviv, Ukraine

3 - Kyiv National Economic University Named After Vadym Hetman, Kyiv, Ukraine

4 - Zhytomyr Polytechnic State University, Zhytomyr, Ukraine

5 - Odesa State Agrarian University, Odesa, Ukraine

\title{
STATE REGULATION OF ENVIRONMENTAL SAFETY
}

Purpose. To conduct a systematic analysis of the state environmental policy, to identify threats to ecologization and the necessary directions for improvement of the state environmental policy.

Methodology. To perform scientific research there were used: the method of content analysis - to assess the scientific achievements and identify unresolved aspects of the problem; method of comparative analysis for evaluation and processing of statistical information; method of analysis and synthesis to form the purpose of the study; methods of abstraction and generalization, formalization - for detailed elaboration of various aspects of the problem; system-structural method and the method of convergence from the abstract to the concrete - for the formation of conclusions and proposals.

Findings. New risks and threats to the state environmental policy have been identified and their impact has been analyzed. The analysis revealed that the state environmental policy does not always extend into regional and sectoral environmental policy. It is established that departmental structures responsible for environmental monitoring do not have proper coordination of their actions, even in time, which complicates integrated information processing. In many areas there is no long-term state forecasting of environmental and economic factors. There is no adequate level of systematization in the formation of structured economic and tax incentives for the introduction of effective environmental technologies and compliance with norms and rules in environmental protection.

Originality. A systematic analysis of the state environmental policy has been carried out, the formation of the emergent nature of ecological and economic factors has been indicated. Mechanisms of the state ecological policy have been formulated. Threats for ecologization policy and necessary directions of improvement of the state ecological policy have been detected.

Practical value. The results of statistical analysis can be used by scientists and practitioners. To reform environmental and economic policy, the threat of imbalance in economic and tax incentives for greening has been pointed out, which may lead to delays in the development and slowdown of technological renewal of industrial sectors, in particular, the energy sector. It has been pointed out that the state ecological and economic policy should be a systemic tool of social policy, help stabilize the situation and overcome the crisis in all spheres of life. The importance of the role of the civil sector in the ecologization of the country and of the need to form a system for developing the environmental consciousness of society has been indicated.

Keywords: ecological safety, state environmental policy, natural capital, state mechanisms

Introduction. Environmental safety is one of the main priorities of state policy. With the devaluation of the role of state institutions, economic, political, social crisis, the implementation of effective state environmental policy is beginning to play not only environmental role, important for the health of citizens, but also becomes an important factor in stabilizing the situation in these areas.

The experience of countries with developed economies shows that without the active role of the state in regulating environmental and economic processes there can be not only environmentally oriented policy and effective formation of environmental security, but also effective social policy. Unfortunately, there are a number of factors that hinder ecologization.

Ukraine has signed a number of international agreements that impose certain obligations to improve the environment. But today, even proper environmental monitoring in accordance with current legislation in some regions is difficult or impossible. In particular, the occupied area of Donetsk and Luhansk regions, the war zone, are beyond the control of state structures responsible for environmental protection measures. This indicates that today additional conditions and special requirements for the implementation of state environmental policy have been formed.

Literature review. The problem of effective state regulation of environmental safety is urgent for Ukraine. Therefore, many scientists have devoted their work to its study. Kalashnyk

(C) Fatkhutdinov V., Yarmol L., Musiiets T., Lagovska O., Kryukova I. 2021
[1], in particular, studied the peculiarities of environmental management in the country, the structure of this management, and the main problems of environmental safety. Koveino [2] identified areas for improvement of existing environmental legislation, and pointed out the shortcomings of state policy in the sphere of environmental safety. Andreichenko, et al. [3] studied the factors of environmental safety in the processes of state regulation of economic and environmental relations. Bespalova [4] analyzed the state policy of EU countries in regulating public relations regarding the maintenance of environmental safety, compared the structure and content of environmental legislation of EU countries with Ukraine. Latysheva [5] developed a system of indicators "assessment of components of environmental safety - man-made and natural safety in the context of their combination in the form of natural and man-made safety" and proposed the elaboration of development scenarios for effective state environmental policy. Dereviahina [6] insists that public environmental policy should be exclusively public and offers means of public environmental management. Ostrovskyi [7] proposes the introduction of measuring the social effectiveness of environmental events on the basis of the study on modern experience of developed countries. Fedorkin [8] analyzed the experience of EU countries on national regional environmental policy. Rdzanek [9] also studied the legal aspects of the regulation of state environmental policy. Andronov [10] studied the peculiarities of the organization of state environmental monitoring in the war zone. Nitsenko, et al. [11] analyzes the aspects and approaches of politics in the context of globalization, includ- 
ing renewable sources, and analyzes the environmental crisis in Ukraine. Lutkovska [12] identified the necessary features of the structure of environmental safety for the effective implementation of state environmental policy. Shvets [13] studied the trends that characterize the current principles of implementation of state environmental policy in Ukraine. Krichevsky [14] proved that the quality of public administration weakens the inverse relationship between ethnic fractionalization and the environmental situation. In [15], Koziuk studies the relationship between government policy and oligarchic economics and ecologization barriers. Foreign scholars, in particular, Maund [16] have studied how policy approaches affect the disparity between the intentions and results of regulatory policy of environmental planning. Pain [17] developed detailed recommendations for managers and professionals on the specifics of compliance with environmental regulations, in particular, ISO requirements.

At the same time, despite a thorough coverage of this problem in the scientific literature, there are still unexplored aspects.

Unsolved aspects of the problem. This analysis of scientific works is a significant basis for achieving the appropriate level of solving many complex problems of ecologization policy. Unfortunately, domestic scientists have not paid attention to the importance of the proper level of systemic nature of this policy and the emergence of components of the economy and ecology in the country. Also, the importance of forming a single effective long-term consistent state ecologization policy which should include the formation and strengthening of the institutional and institutionary system of management and monitoring of the ecological and economic situation in the country was out of consideration.

The purpose of the article is to conduct a systematic analysis of the state environmental policy, identify threats to ecologization and the necessary areas for improvement of state environmental policy.

Methods. The implementation of scientific research, the result of which is the presented article, required the systematic application of general and special scientific methods: the method of content analysis to assess the scientific achievements on the identified issues and identify unresolved aspects of the problem; method of comparative analysis for evaluation and processing of statistical information; method of analysis and synthesis to form the purpose of the study; method of abstraction and generalization, method of formalization - to solve problems, detailed development of various aspects of the scientific problem; system-structural method and the method of convergence from the abstract to the concrete - for the formation of conclusions and proposals.

Results. The state policy of ecologization is, first of all, the policy aimed at implementation of the constitutional norms on ensuring ecological safety (Article 16. Ensuring ecological safety and maintaining ecological balance on the territory of Ukraine, the Constitution of Ukraine). But it is also a policy aimed at reducing economic costs and social and political risks in the future to eliminate the effects of today's anti-environmental economic activities, to preserve and increase the country's natural capital, to comply with international agreements on environmental protection.

The state policy of ecologization has many directions, spheres of anthropogenic influence, the ordering of which has its own peculiarities, its own mechanisms, its own level of influence on the environment. This creates special requirements for the systemic nature of this policy.

The state policy of ecologization is based on a set of legal acts on environmental protection. When forming this complex, legislators were aware of the depth of the problem. Thus, in the resolution of the Verkhovna Rada "Main directions of Ukraine's state policy in the field of environmental protection, use of natural resources and environmental safety" already in 1998, the environmental situation in Ukraine was recognized as critical and the task of forming a system of ecologically balanced public development focused on environmental restoration and efficient use of natural capital was defined.

Unfortunately, this resolution, like some others, was of rather declarative character. The directions of environmental policy were set, but their practical implementation turned out to be more multifactorial than it was previously thought, complicated by new threats. Therefore, nowadays, according to the Environmental Performance Index (EPI), Ukraine ranks $60^{\text {th }}$ out of 180 countries in the world - in the first third of the list (Table 1) [18]. For 10 years, the country has improved the EPI Score by only 0.7 points. This is not a very comforting result compared to neighboring countries, some of which are improving the value of EPI at a rate that exceeds the Ukrainian by an order (Table 1). This indicates, in particular, the lack of efficiency of environmental public management.

A comparative analysis of the implementation of state environmental and economic policy in different countries indicates its dichotomy. On the one hand, the instrument of economic impact on citizens and businesses to comply with environmental standards and a consistent policy of raising them is a tax environmental policy.

At the same time, the pace of increasing responsibility in the face of rising environmental standards must correlate with the growth of environmental awareness of society, otherwise it may cause public protests and political destabilization. However, the implementation of this tool has another side. Countries that reduce their own anthropogenic impact on the environment that is common to all inhabitants: the atmosphere, hydrosphere, and so on should pay by fiscal pressure on their producers, which, in turn, is a burden on national economies, reducing their international competitiveness.

The state policy of ecologization on the condition of introduction of economic pressure on citizens and businesses affects such macroeconomic characteristics as employment, exports of goods and services, income distribution, profits of businesses and industries, and others.

There are countries that minimize environmental measures to achieve specific macroeconomic results, and this can unfortunately be a negative example for national economies under significant pressure from the crisis, for third world economies and countries that implement policies of environmental and economic selfishness. Unfortunately, the policy of environmental and economic selfishness is acceptable even to such economic leaders as China.

At the same time, the analysis shows that a significant level of differentiation in the environmental policy of the world sometimes contributes to the corporate policy of the world's leading countries, aimed at minimizing costs by neglecting the environment protection of other countries. Corporations implement policies of environmental and economic selfishness and place potentially environmentally harmful industries in countries where labor is cheap and environmental regulations are lenient. Mostly these are third world countries. This exacerbates the political, economic, and national problems of poor

Table 1

Comparison of the Environmental Efficiency Index in Ukraine and neighboring countries

\begin{tabular}{|c|l|c|c|c|}
\hline No & Country & Rank & EPIScore & 10-year change \\
\hline 1 & Ukraine & 60 & 49.5 & 0.7 \\
\hline 2 & Estonia & 30 & 65.3 & 4.3 \\
\hline 3 & Romania & 32 & 64.7 & 8.1 \\
\hline 4 & Poland & 37 & 60.9 & 1.1 \\
\hline 5 & Bulgaria & 41 & 57 & 4.2 \\
\hline 6 & Belarus & 49 & 53 & 2.3 \\
\hline
\end{tabular}


countries. That is why such corporate (and not only corporate) policy is called "environmental racism" or "path of least resistance". This means that the relationship between national income and the level of man-made pollution - the so-called "environmental Kuznets curve" is now transnational in nature.

The analysis of the ecological and economic situation in Ukraine, using the mentioned method of Kuznets, allowed establishing the following: the transition from the industrial post-Soviet economy to the post-industrial information economy in the realities of Ukraine is complicated by the formation of a clan-oligarchic system. Moreover, a characteristic feature of the Ukrainian clan-oligarchic system is that it uses mainly the raw material factor using differences in world prices for raw materials and preferences in its extraction and transportation, i.e. poor quality of national institutions are produced.

This leads to inconsistency of political and economic transformations in the country.

The consequence of this is: a "wild" change in the structure of the economy, which generates a significant anthropogenic impact on the environment; corporate minimization of expenditures on energy efficient and environmental technologies; increasing inequality in income distribution; illegal redistribution of public property, the practice of raider seizures, which almost automatically leads to the deterioration of the ecological and economic situation of the seized property; formation of a significant share of the shadow sector in the country's economy, which is characterized by neglect of social and environmental interests in income generation (deforestation, wasteful exploitation of deposits, unlicensed mining, etc.).

Pauperization of the population reduces the social demand for an environmentally friendly environment, and reduces the possibility of public funding of environmental projects.

Significant growth of political and social challenges, military actions on the territory of the country reduce the possibility of public pressure on corporate polluters, the imposition of environmental requirements on regional and state institutions.

Declining public awareness of the state of the environment leads communities to respond only to direct environmental challenges - illegal placement of unauthorized landfills, a sharp deterioration in organoleptic qualities and taste of drinking water, the stench of non-functioning sewers and so on. Implicit factors of pollution do not cause the protest.

Inequality in income distribution, the formed clan-oligarchic system is illustrated by the value of the Hofstede Index (PDI) for Ukraine [19]. This index indicates the degree of distance of people (the opposite of the concept of social interaction) at different levels of the social hierarchy. For Ukraine, the Hofstede index is equal to PDI $=92$, which is only 8 points less than the largest negative value, which indicates significant social inequality and characterizes the inadequate level of development of civil society. Even for India, which is considered a country with a historically rooted caste society, the Hofstede index is lower (PDI =77). Inadequate level of development of civil society hinders the achievement of common environmental goals, activity in defending the proper quality of life.

The above-mentioned analysis shows that according to the Kuznets method, the U-shaped effect for Ukraine is in the extreme zone.

This is evidence that the opportunities to improve the environmental situation in a rapid and efficient manner are insufficient. Awareness of this fact should contribute to the formation of a realistic environmental policy of the state and the development of effective tactics and strategies for civil society.

This analysis also proves that in the current circumstances, the state policy of ecologisation, reducing environmental risks is a complex long-term process, one of the main characteristics of which should be consistency and strategic planning with appropriate dynamic adjustment of its implementation in accordance with comprehensive monitoring.
At the same time, state regulation and management in the field of environmental safety, environmental public management must nowadays meet new challenges and threats that form new requirements for its effectiveness and efficiency. Thus, at present the political, economic and social spheres are destabilized by the factor of military action. These military actions create an unprecedented level of environmental threats, which is not confined to the combat zone $[10,20]$.

Environmental policy does not have a cross-cutting systemic character, which also carries a new level of environmental threats. This is due, in particular, to the fact that the state environmental policy is not extended into regional and sectoral environmental policy, which is complicated by the outdated level of technologies used in industry.

Departmental structures responsible for environmental monitoring do not have proper coordination of their actions, even in time, which complicates the integrated processing of information.

This creates a significant level of environmental danger for neighboring countries. Thus, among the thirty coal-fired power plants in Europe that most pollute the atmosphere with sulfur dioxide, nitrogen oxides, and fine solid particles, 12 are located in Ukraine. Ukrainian thermal power plants account for two thirds of the total air pollution of European countries with fine solid particles. The second largest polluting country is Turkey with six power plants. This is due to the fact that nowadays Ukraine receives $34 \%$ of the amount of electricity from old coal-fired power plants, which are not equipped with treatment technologies. Re-equipping old CHPs with new technologies of proper environmental protection is economically unsubstantiated.

This makes it extremely urgent for the state environmental management to create conditions for the transition of the country's energy to another technological level, in particular, the use of alternative and renewable energy sources.

One of the traditional renewable sources of electricity for Ukraine is hydropower.

Let us analyze the efficiency and consistency of the policy of replacing coal energy with hydropower, based on state statistics (Fig. 1).

Even the nature of the graphical dependence of energy production by hydroelectric power plants indicates significant fluctuations over time. The trend towards stable growth begins to appear only in 2015 . Even the relatively politically stable period up to 2013 is characterized by fluctuations of indicators more than 1.5 times. This is not evidence of the consistency of the implementation of policies to replace environmentally harmful technologies.

It is impossible not to say about the lack of a consistent project approach in this area. A positive fact, in particular, is the completion of the construction of Tashlyk PSP, raising the level of Alexander Reservoir to 20.7 meters. This removes the risks of uneven peak loads for the South Ukrainian NPP, threats of uneven operation of the country's energy system,

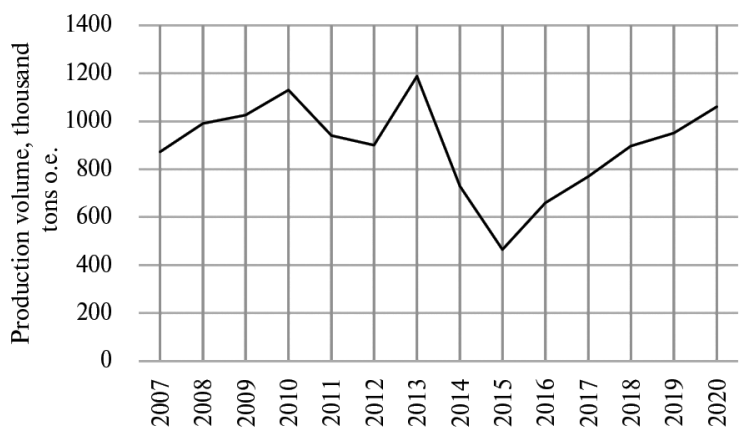

Fig. 1. Dynamics of energy production by hydroelectric power plants, thousand tons of oil equivalent 
creates an emergency reserve of high-speed energy capacity and is an example of long-term plans for ecologization of Ukraine. However, the implementation of one project or even a group of projects does not indicate a systematic approach to the implementation of a purposeful consistent long-term economic and environmental policy.

This conclusion is confirmed by the analysis of the dynamics of capital investment in environmental protection (Fig. 2). The graphical representation of this indicator shows a significant unevenness from year to year. Fluctuations in the volume of capital investment in environmental protection as a whole from year to year are sometimes more than $69 \%$ (2018 to 2019).

At the same time, the analysis of capital expenditures for air protection and solving climate problems since 2015 indicates a steady upward trend (Fig. 2). That is, the consistency of state environmental policy is sectoral, not systemic.

The ratio of capital investment in air protection and climate change from 2015 to 2020 has more than tripled. This, in general, is in line with the state's environmental policy aimed at the gradual implementation of international agreements in this area by Ukraine.

The share of energy supply from alternative sources to the total amount of energy produced is still insignificant (Fig. 3). But the study found a characteristic consistent trend towards growth of this indicator. So, from 2007 to 2018, this share has more than tripled.

The explanation of certain discrepancies in the environmental and economic policy of Ukraine and the European Community is a comparative analysis of the structure of environmental expenditures by funding sources. Funds from the state and local budgets and other sources of funding for these purposes in Ukraine account for only $13.1 \%$ of total funding. Everything else is enterprises' and organizations' own funds (Fig. 4).

The sources of funding for environmental measures in the European Community are more diverse. This is a system of grants, environmental funds, international environmental programs, which are the greater part in the cost structure for these purposes.

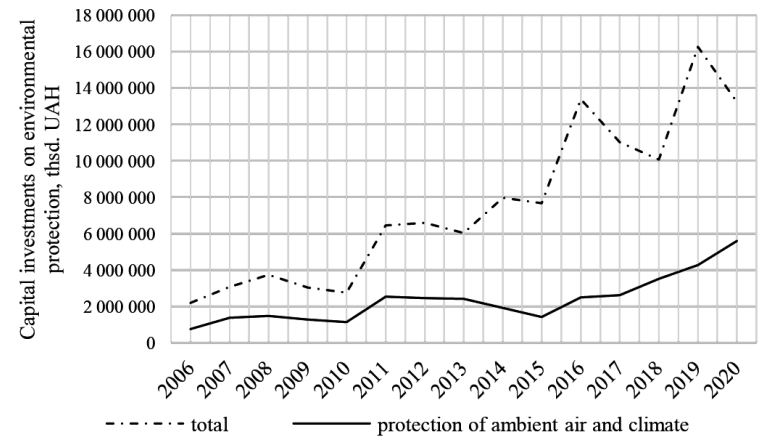

Fig. 2. Dynamics of capital investments in environmental protection by types (in actual prices; thousand $U A H$ )

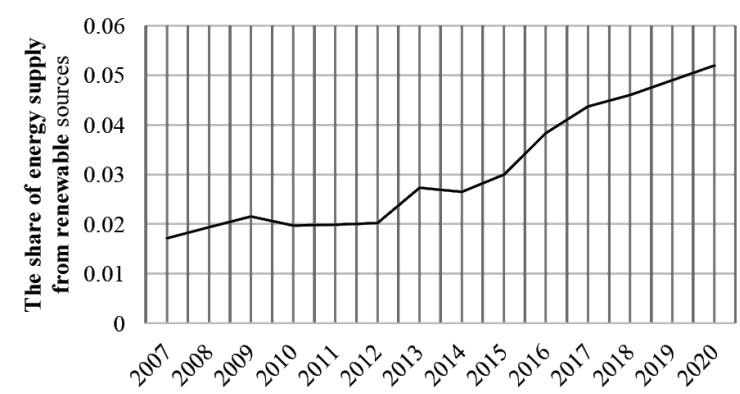

Fig. 3. Dynamics of the share of energy supply from renewable sources to the total amount of energy produced

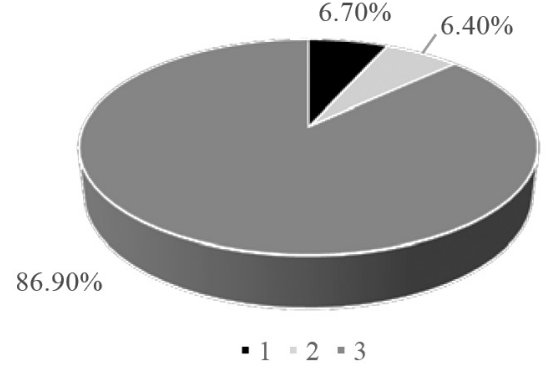

Fig. 4. The structure of expenditures for environmental protection by funding sources, \%:

1 - funds of state and local budgets; 2 - other sources of funding; 3 - enterprises' and organizations' own funds

At the same time, a significant part of the costs of environmental protection from enterprises and organizations in Ukraine indicates the implementation of state regulatory and tax policies to minimize environmental threats. The lack of financial resources in the state and regional budgets for environmental purposes is compensated by the corporate sector. But the use of this resource inevitably leads to an increase in the cost of products and services of business entities, reducing the financial capacity to renew their own production of state corporations, i.e. has a significant negative impact on economic performance. Therefore, the pace of neutralization of environmental threats, especially in the context of their growth cannot be significant.

An analysis of existing mechanisms of state regulation and management in the sphere of environmental safety (Table 2). They represent both economic and non-economic aspects of neutralizing environmental risks and threats. On the other hand, they also reflect the need to raise the level of social and environmental awareness of citizens.

A comparative analysis of ecologization in the EU shows that ecologization policy is based on a balance of administrative and financial mechanisms. Financial and economic mechanisms are based on the principles of ecological accounting and an effective system of $\sim 150$ types of ecological taxes

Table 2

Mechanisms of regulation and management in the sphere of environmental safety

\begin{tabular}{|c|l|}
\hline No. & \multicolumn{1}{|c|}{ Name } \\
\hline 1 & State cadasters and accounting of natural capital objects \\
\hline 2 & $\begin{array}{l}\text { The system of state institutions that form the state } \\
\text { environmental policy, directly carry out environmental } \\
\text { activities and control the state of the environment }\end{array}$ \\
\hline 3 & $\begin{array}{l}\text { Certification, licensing, audit and control of the use of } \\
\text { natural resources }\end{array}$ \\
\hline 4 & Formation of standards of industrial load on the environment \\
\hline 5 & $\begin{array}{l}\text { Formation of a system of economic and tax incentives for } \\
\text { economic entities to implement measures and technologies } \\
\text { for environmental protection }\end{array}$ \\
\hline 6 & Imposition of fines for violation of environmental regulations \\
\hline 7 & $\begin{array}{l}\text { Administrative punishment of violators of environmental } \\
\text { legislation }\end{array}$ \\
\hline 8 & $\begin{array}{l}\text { State registration of the rights of citizens and business } \\
\text { entities to natural objects }\end{array}$ \\
\hline 9 & The system of education of ecological consciousness of society \\
\hline 10 & Environmental audit and publication of its results \\
\hline 11 & $\begin{array}{l}\text { Environmental integration at all levels, including regional } \\
\text { and sectoral ones }\end{array}$ \\
\hline
\end{tabular}


approved in 1993. The structure of these taxes and tariff rates are dynamically regulated in each EU country in accordance with the characteristics of national economies, social and political differences to achieve the general level of established standards. The main principles of environmental policy, reflected in the $6^{\text {th }}$ EU Environment Action Program, adopted in 2002, are not the introduction of the latest treatment systems but the focus on environmentally sound technologies and statutory environmental responsibility.

At the same time, in Ukraine, it is sometimes suggested to focus not on new technologies but on treatment systems, that is, not on long-term environmental policy, but on solving tactical tasks. But, as the experience of the world's leading countries shows, one of the characteristic indicators of the implementation of effective economic and environmental policy and elimination of existing threats to the economy and the environment, which is important for Ukraine, is the adequacy, feasibility and environmental friendliness. An example is the ecologization of energy on the condition that the required amount of energy with the desired structure of these volumes is provided.

Analysis of the dynamics of electricity consumption by sources is given in Table 3. First, there is a decrease in energy consumption by $39 \%$ from 2000 to 2020 . This trend is not an unambiguous characteristic of the positive economic and environmental policy of Ukraine. Formally, it indicates an increase in the energy efficiency indicator of the main energy consumer - industry.

But, as the analysis shows, in practice, the growth of the energy efficiency indicator for the industry of Ukraine is achieved not only by the introduction of new technologies, but also by the cessation of enterprises based on outdated unprofitable material-consuming and energy-consuming technologies. This process is accompanied by a reconstruction of the structure of economic sectors, which is extremely complex and is characterized by significant social and macroeconomic shifts.

For comparison - for the period of 2000-2019, Ukraine's GDP grew from 31.3 billion US dollars up to 167.8 billion US dollars, i.e. by more than 5 times. At the same time, the index of industrial products (industrial production) in Ukraine from 2011 to 01.2019 is $63.5 \%$ with progressive total. That is, there is a significant reduction in this indicator. This can be explained by the fact that industrial enterprises are the main energy consumers in the structure of the country's economy. They influence the level of energy intensity and, accordingly, energy efficiency.

This is evidence that, despite GDP growth, the decline in energy consumption correlates with the decline in industrial production and this is not a purely positive sign of a purposeful policy.

At the same time, the analysis of the data given in Table 3 shows that the reduction in energy consumption occurred primarily due to the reduction of environmentally non-friendly

Table 3

Dynamics of electricity consumption by sources, TeraWatt-hours

\begin{tabular}{|l|c|c|c|c|c|c|}
\hline \multicolumn{1}{|c|}{ Sources } & 2000 & 2005 & 2010 & 2015 & 2019 & 2020 \\
\hline Solar & 0 & 0 & 0 & 1 & 7 & 7 \\
\hline Wind & & & & 3 & 5 & 5 \\
\hline Hydropower & 31 & 33 & 34 & 14 & 17 & 18 \\
\hline Atomic & 215 & 239 & 232 & 222 & 206 & 209 \\
\hline Gas & 742 & 722 & 546 & 320 & 282 & 282 \\
\hline Coal & 443 & 434 & 445 & 318 & 306 & 322 \\
\hline Oil & 145 & 165 & 153 & 108 & 122 & 121 \\
\hline Total & 1581 & 1593 & 1411 & 986 & 945 & 964 \\
\hline
\end{tabular}

technologies: coal energy was reduced by $27.3 \%$, gas combustion -2.63 times, oil - by $16.6 \%$. But during the same period Ukraine began to produce electricity from alternative sources on an industrial scale, at an increasing pace (Table 3 ).

Next, we analyze the dynamics of changes in energy intensity in terms of final energy consumption and the overall supply of primary energy in terms of environmental and economic threats (Table 4). Dynamics of energy consumption indicators given in Table 4 is, on the one hand, an objective indication of excessive environmental impact on inefficient production and consumption of the basis of the modern economy - energy; on the other hand, it is evidence of public policy to eliminate threats related to energy shortages, its inefficient production and consumption.

As it can be seen from the data in Table 4 for the period of 2007-2020 (i.e. for quite a long period of time) energy consumption, tons of oil equivalent/thousand international dollars, the final energy consumption decreased by 1.47 times, and the energy intensity of the total primary energy supply decreased by 1.31 times. This is indicated by the decrease in the absolute value of energy consumption for the entire considered period in 2007-2018. And this is positive evidence of environmental management. At the same time, the analysis of the dynamics of these parameters indicates the unevenness of their improvement from year to year. In particular, the energy intensity indicator tended to deteriorate over the period 20072010 - it increased by $5 \%$. As the comparative analysis shows, today the energy intensity index of Ukraine's GDP is almost twice as large as the corresponding global average. This indicates a certain degree of inefficiency in the management of the overall process of improving energy efficiency in Ukraine.

It is well known that the share of energy costs of all consumers in GDP should be stable. Exceeding this share above the threshold value of $\sim 10-11 \%$ of GDP leads to a slowdown in the country's economic growth.

With the implementation of the policy of increasing energy prices, only increasing the efficiency of their use will ensure the ratio of energy costs to GDP within the limits that will allow increasing its own GDP.

That is, the key and a sign of the effectiveness of economic and environmental policy is the growth of the above-mentioned energy efficiency factor. The energy efficiency factor, as shown above, is improving in the country. The problem for Ukraine is the relatively low rate of improvement of this indicator. This should be facilitated by an effective long-term environmental and economic regulatory policy of the state. Therefore, in order to implement this long-term state policy aimed at technical and technological renewal of energy, the level of environmental taxes should be stimulating, not delaying the development of the energy sector.

At the same time, as the analysis shows, the state regulatory policy in this area is characterized by the following:

1. There is no long-term forecasting of energy costs at the state level.

2. Systematic energy use policy is insufficient.

3 . Incentives for the introduction of energy efficient technologies do not work properly.

This analysis shows that the consistency and planning of public policy in this area are insufficient.

Table 4

Dynamics of energy consumption, tons of oil equivalent/ thousand international dollars

\begin{tabular}{|l|c|c|c|c|c|}
\hline \multirow{2}{*}{ Parameter } & \multicolumn{5}{|c|}{ Years } \\
\cline { 2 - 6 } & 2007 & 2010 & 2015 & 2018 & 2020 \\
\hline By final energy consumption & 0.217 & 0.206 & 0.159 & 0.148 & 0.148 \\
\hline $\begin{array}{l}\text { According to the total supply } \\
\text { of primary energy }\end{array}$ & 0.352 & 0.368 & 0.282 & 0.269 & 0.268 \\
\hline
\end{tabular}


Since, as noted above, the country's environmental policy has many areas, spheres of anthropogenic impact, the regulation of which has its own characteristics, mechanisms, its own level of environmental impact, let us analyze, as a positive example, the implementation of state policy in reforestation.

The media have formed a stable public perception of the catastrophic situation in this sphere, due to the alleged "wasteful deforestation". However, the analysis of the state policy of reforestation established (Table 5) the appropriate rate of reforestation, which not only exceeds the rate of loss of forest stands but provides recovery, greater than the total amount of loss and afforestation (Table 5).

According to state statistics for 1983, the area of forests in Ukraine was $\sim 9.969$ million hectares, which corresponds to the country's forestry index of $16.52 \%$. In 2016, these indicators amounted to 10.633 million hectares and $17.62 \%$, respectively.

The real rate of forest cover today is even higher, because if not cleared, land that has not been restored by the owners and is actually outside the state statistics of reforestation, is overgrown naturally with wild plants. Therefore, according to expert estimates, the forest cover index today is $\sim 20-22 \%$. This is due to the fact that timber is cut in farms (forestry), which are strictly controlled by the relevant state institutions, so and in a purposeful and organized way restore the cleared forest area. In particular, in 2019, 254 million saplings were planted by forestry alone, according to the planned annual work.

The example of the implementation of the state policy of reforestation shows the achievement of a consistent and effective planned environmental and economic policy and the need for its systematic implementation in all areas.

Conclusions. Nowadays, given the military actions on the territory of Ukraine, the growing effects of the economic and social crisis, the importance of effective environmental policy is gaining new meaning.

It has been established that, in general, Ukraine's environmental policy is not of a cross-cutting systemic nature, which, in some areas, also creates a new level of environmental threats. Thus, the analysis in the environmental and energy sphere shows that the state environmental policy does not always have an extension into the regional and sectoral environmental policy. At present departmental structures responsible for environmental monitoring do not have proper coordination of their actions, even in time, which complicates the integrated processing of information.

In many areas there is no long-term state forecasting of environmental and economic factors. There is an inadequate level of systematization in the formation of structured economic and tax incentives for the introduction of effective environmental technologies and compliance with norms and rules in environmental protection. This leads to some imbalance in the policy of economic and tax incentives for ecologization, which, in some cases, leads to the formation of trends of additional tax pressure on enterprises, which, in turn, may delay the development and technological renewal of industrial sectors, including the energy industry.

Ukraine needs to pursue a single effective long-term consistent state policy of ecologization, which should include the formation and strengthening of the institutional and institutionary system of management and monitoring of the ecological and economic situation in the country.

This policy should be aimed not only at solving environmental and economic problems but should be a systemic tool of social policy, a factor that contributes to the stabilization of the situation in all spheres of life. Unbalanced use and depletion of natural capital must be stopped.

One of the mechanisms for this is to strengthen the role of civil society, so one of the directions of the state policy of ecologization should be the formation of a system of creating environmental awareness of citizens.

\section{References.}

1. Kalashnyk, O. (2018). Ecological safety as a component of the public policy of Ukraine: conceptual-terminological aspects. Academic papers collection. "Democratic governance", 21, 1-8. https://doi. org/10.33990/2070-4038.21.2018.151074.

2. Koveino, Yu.V., \& Dresvyannikova, V.D. (2019). Legal regulation of environmental safety. Prykarpattya Legal Bulletin, 2(27), 68-73. https://doi.org/10.32837/pyuv.v0i2(27).191.

3. Andreichenko, A., Andreichenko, S., \& Smentyna, N. (2021). Ensuring Biosphere Balance in the Context of Agricultural Waste Management. Philosophy and Cosmology, 26, 46-61. https://doi. org/10.29202/phil-cosm/26/4.

4. Bespalova, O. (2020). Ecological policy of EU countries regarding the regulation of public relations in the field of maintaining environmental safety. Bulletin of VN Karazin Kharkiv National University. Law Series, 2(30), 147-155. https://doi.org/10.26565/2075-18342020-30-17.

5. Latysheva, O., Pidhora, Ye., Kasianiuk, S., \& Vizirov, V. (2020). Natural and Technological Safety and Environmental Safety: the Essence, Indicators of Assessment, the Role in the Formation of the National Security Strategy of the State. Economic Bulletin of Donbass, 1(59), 145-161. https://doi.org/10.12958/1817-3772-20201(59)-145-161.

6. Dereviahina, N., \& Sychova, M. (2020). Means of public administration of environmental protection in Ukraine. Investments: practice and experience, 17-18, 111-115. https://doi.org/10.32702/23066814.2020.17-18.111.

7. Ostrovskyi, I. A., Rybak, H. I., \& Haidenko, S. M. (2018). Measurement of social effectiveness of environmental activities: international experience and problems of Ukraine. Economy and society, $16,3-8$.

8. Fedorkin, D.V. (2017). State adjustment of the environmental safety: foreign experience. Scientific Papers of the Legislation Institute of the Verkhovna Rada of Ukraine, 3, 97-105. https://doi.org/10.32886/instzak.2017.03.15.

9. Rdzanek, D. (2021). Implementation of the mechanisms of the European Union 's Common Agricultural Policy in Poland - lessons for Ukraine. Ukrainian Policymaker, 8, 102-107. https://doi.org/10.29202/ up $/ 8 / 10$.

10. Andronov, V. A., \& Horinova, V. V. (2017). Level of organization of state ecological monitoring in the zone of hostilities (Donetsk and Luhansk regions). Retrieved from http://repositsc.nuczu.edu.ua/bitstream/123456789/355/1/30.PDF.

11. Nitsenko, V., Mardani, A., Streimikis, J., Shkrabak, I., Klopov, I., Novomlynets, O., \& Podolska, O. (2018). Criteria for Evaluation of Efficiency of Energy Transformation Based on Renewable Energy Sources. Montenegrin Journal of Economics, 14(4), 253-263. https:// doi.org/10.14254/1800-5845/2018.14-4.17.

Dynamics of forest reproduction

\begin{tabular}{|l|c|c|c|c|c|c|}
\hline \multirow{2}{*}{\multicolumn{1}{|c|}{ Parameter, ha }} & \multicolumn{5}{c|}{ Years } \\
\cline { 2 - 8 } & 2010 & 2015 & 2016 & 2017 & 2018 & 2020 \\
\hline Area of death of forest plantations & 20864 & 27768 & 19405 & 20111 & 15069 & 39756 \\
\hline Area of forest reproduction by natural regeneration & 70084 & 60402 & 63226 & 64713 & 51519 & 54924 \\
\hline Afforestation area & 27798 & 2521 & 2886 & 2198 & 2257 & 2309 \\
\hline Reforestation area & 42286 & 57881 & 60340 & 62515 & 49262 & 42489 \\
\hline
\end{tabular}


12. Lutkovska, S. (2020). The essence of the system of environmental safety of sustainable development in the conditions of global economy. Efficient economy, 4, 1-10. https://doi.org/10.32702/2307-21052020.4.56.

13. Shvets, V. A. (2020). Theoretical foundations for the implementation of state environmental policy in Ukraine. Public administration and customs administration, (1), 5-8. https://doi.org/10.32836/23109653-2020-1.1.

14. Krichevsky, S., \& Levchenko, V. (2021). Human Life and Evolution in Biospheres on Earth and Outer Space: Problems and Prospects. Future Human Image, 15, 39-58. https://doi.org/10.29202/ $\underline{\text { fhi } / 15 / 4}$.

15. Koziuk, V., Dluhopolskyi, O., Farion, A., \& Dluhopolska, T. (2018). Crony Sectors as a Barrier to Economic Well-Being and Ecologization (Case of Ukraine). Economics and Sociology, 11(3), 113-132. https://doi.org/10.14254/2071- 789X.2018/11-3/7.

16. Maund, K., Gajendran, T., \& Brewer, G. (2018). Key Issues for Implementation of Environmental Planning Policy: Construction Management Practice. Sustainability, 10, 2156. 1-13. https://doi. org/10.3390/su10072156.

17. Pain, S.W. (2018). Safety, Health and Environmental Auditing: A Practical Guide, Second Edition Boca Raton. London: CRC Press. Retrieved from https://www.routledge.com/Safety-Health-and-Environmental-Auditing-A-Practical-Guide-Second-Edition/Pain/p/ book/9781138557154.

18. Environmental Performance Index (2021). 2020 EPI Results. Results Overview. Retrieved from https://epi.yale.edu/epi-results/2020/ component/epi.

19. The state of Ukrainian legislation governing environmental and man-made risks in the context of the priorities of the Sendai Framework Program for Emergency Risk Reduction (2020). Analytical report. Project "Reducing the risk of disasters and vulnerability of the population in Eastern Ukraine". Retrieved from https://r2p.org.ua/ wp-content/uploads $/ 2020 / 10 /$ report_on_eco_tech_risks_3p-consortium.pdf.

20. Strategic Environmental Assessment (SEA) implementation experience in Ukrainian cities (2019). PROMIS project. Retrieved from https://decentralization.gov.ua/uploads/library/file/529/KeysStudy-CEO.pdf.

\section{Державне регулювання екологічної безпеки}

\section{В. Г. Фатхутдінов ${ }^{1}$, Л. В. Ярмол ${ }^{2}$, Т. В. Мусієць ${ }^{3}$, О. А. Лаговська ${ }^{4}$, І. О. Крюкова}

1 - Міжрегіональна Академія управління персоналом, м. Київ, Україна; e-mail: mfkoorg@gmail.com

2 - Національний університет «Львівська політехніка», м. Львів, Україна

3 - Київський національний економічний університет імені Вадима Гетьмана, м. Київ, Україна

4 - Державний університет «Житомирська політехніка», м. Житомир, Україна

5 - Одеський державний аграрний університет, м. Одеса, Україна
Мета. Провести системний аналіз державної екологічної політики, виявити загрози екологізації та необхідні напрями вдосконалення державної екологічної політики.

Методика. Для виконання наукового дослідження застосовано: метод контент-аналізу - для оцінки наукового доробку й виявлення невирішених аспектів проблеми; метод порівняльного аналізу для оцінювання та обробки статистичної інформації; метод аналізу й синтезу - для формування мети дослідження; методи абстрагування та узагальнення, формалізації - для детальної розробки різних аспектів проблеми; системно-структурний метод і метод сходження від абстрактного до конкретного - для формування висновків і пропозицій.

Результати. Встановлені нові ризики й загрози державної екологічної політики та проаналізовано їх вплив. Проведеним аналізом виявлено, що державна екологічна політика не завжди має подовження в регіональній і галузевій екологічній політиці. Встановлено, що відомчі структури, відповідальні за моніторинг довкілля, не мають належної узгодженості своїх дій навіть у часовому вимірі, що ускладнює інтегровану обробку інформації. За багатьма напрямами відсутнє довгострокове державне прогнозування еколого-економічних чинників. Наявний неналежний рівень системності у формуванні структурованого економічного й податкового стимулювання до запровадження ефективних природозахисних технологій і дотримання норм і правил у збереженні довкілля.

Наукова новизна. Проведено системний аналіз державної екологічної політики, указано на формування емерджентного характеру еколого-економічних чинників. Сформульовані механізми державної екологічної політики. Виявлені загрози політики екологізації та необхідні напрями вдосконалення державної екологічної політики.

Практична значимість. Результати статистичного аналізу можуть бути використані науковцями та практиками. Для реформування еколого-економічної політики вказано на загрозу дисбалансу в економічному й податковому стимулюванні екологізації, що може призвести до затримання розвитку та уповільнення технологічного оновлення секторів промисловості, зокрема, енергетичної галузі. Указано на те, що державна еколого-економічна політика має бути системним інструментом соціальної політики, сприяти стабілізації ситуації й подоланню кризи в усіх сферах життя країни. Указано на важливість ролі громадянського суспільства в екологізації країни, і необхідності формування для цього системи виховання екологічної свідомості громадян.

Ключові слова: екологічна безпека, державна екологічна політика, природний капітал, державні механізми

Recommended for publication by O. Chukurna, Doctor of Economic Sciences. The manuscript was submitted 11.03.21. 